\title{
An Empirical Study on Multimedia-based Social Constructivist Model in English Vocabulary Acquisition
}

\author{
Xiaohong Du \\ Foreign Languages School of Zhengzhou University, Zhengzhou, 450001, China
}

\begin{abstract}
Basing on the aid of multimedia, this paper aims at investigating the development of students' controlled and free productive vocabulary through the application of the social constructivist model to a classroom vocabulary empirical study, so as to find out the relationship between FL learners' vocabulary acquisition and their application of social constructive model with the help of multimedia. On the basis of the results from this study, we attempt to put forward a new vocabulary acquisition model which combines the acquisition with production: combination of input and output, which will help FL learners narrow down the gap between their negative vocabulary and positive vocabulary under non-native environment.
\end{abstract}

Index Terms-multimedia, social constructivist model, free-productive vocabulary, controlled-productive vocabulary

\section{INTRODUCTION}

As we know, vocabulary acquisition is an indispensable part in the process of language acquisition, especially in English as a second or foreign language. During the last two decades, though there has been a growing interest in vocabulary acquisition among second language teachers and researchers, and the research stockpile has expanded in scope and complexity at a remarkable rate in and abroad. However, the studies by far, including both breadth and depth of vocabulary study, mainly concern how to help learners grasp the basic receptive (passive) knowledge, i.e. understanding the most frequent and core meaning of a word, while neglect FL learners' vocabulary competence improvement. That is the key reason why most FL learners who have relatively large vocabulary still could not produce words freely in their speaking and writing. The introduction and widely use of Internet and multimedia in English vocabulary acquisition will, to a certain degree, contribute to help students narrow the gap between their negative and positive vocabulary.

How to help learners apply their acquired vocabulary knowledge into their vocabulary competence is becoming more and more important in the field of vocabulary study. This paper aims at investigating the development of students' controlled and free productive vocabulary through the application of the social constructivist model to a classroom vocabulary empirical study with the help of computer and multimedia, so as to construct a new vocabulary acquisition model which combines the vocabulary acquisition with output or production. That is, ask students to output the newly-learned words in multimedia-based social interactive situations created by themselves with the help of teachers.

This paper includes quantitative and qualitative research. To the results of vocabulary tests and the questionnaire, SPSS was adopted to analyze the research findings. Inductive method was also used to analyze the data. The findings demonstrate the positive relationship between students' vocabulary knowledge acquisition (the controlled-productive and free-productive vocabulary) and their application of multimedia-based social constructivist model. The results of this study, in a way, will help FL learners shorten the gap between their receptive and productive vocabulary.

\section{Multimedia-Based Social Constructivist Model}

Social constructivist model is put forward by Marion Williams and Robert L. Burden in 1997, which mainly based on different approaches of educational psychology such as, humanism, social interactionism and constructivism. In this model, there are four key sets of factors which influence the learning process--- teachers, learners, tasks and contexts, and none of these factors exists in isolation. They all interact as part of a dynamic, ongoing process. The social constructivist model puts the emphasis on the dynamic nature of the interplay between teachers, learners and tasks. Since learning never takes place in isolation, the social constructivist model focuses the importance on learning environment or context within which the learning takes place. From a social constructivist view, learning is the process of constructing knowledge in social environments, not merely obtaining it, but applying it within a social interactionist framework. With the advent and popularity of Internet and multimedia, more and more teachers have adopted the new technology to provide students with real or native-like language environments and vivid contexts. Introducing the internet and multimedia into English teaching is an inexorable trend in FL teaching and research. Multimedia-based teaching can help FL learners digest the abstract words through pictures and other animation or cartoons (Du Xiaohong, 
2009, 2011). Besides, multimedia-based teaching can provide learners with sounds, pictures, electronic texts, cartoons and native-like contexts, which can not only stimulate learners' interest, but also can help them understand some abstract words easily. The effective use of internet and multimedia, on the one hand, can help teachers convey class information quickly and make the content of courses more substantial, on the other hand, can help learners use vivid and authentic language to communicate meaningfully. And students will be more active in learning under such class environment. Research suggests that learners produce longer sentences and negotiate meaning more often in pair and group work than in teacher-fronted instruction (Doughty \& Pica, 1986). Under multimedia-based teaching environment, teachers can provide learners with opportunities to share ideas about the newly-learned words in real or real-like situations, which is very beneficial to activate their latent word stores and apply their newly-learned words into practice. In this paper, we'll apply Social constructivist model into our class vocabulary teaching with the help of internet and multimedia. It will, in a way, prompt the effect of adopting social constructivist model in classroom vocabulary teaching.

\section{ReSEARCH DESIGN}

\section{A. Subjects}

The subjects in this study were 74 freshmen in two classes selected from Zhengzhou University, majoring in International Trade. Group one (the controlled group) consists of 37 students from Class One, among them, 21 are female and 16 are male. Group Two (the experimental group) includes 37students from Class Two, among them, 19 are female and 18 male. The age ranged from 17 to 21. Approximately two-thirds of the subjects are from Henan province; the rest are mainly from different areas of China. All students were enrolled according to their scores in China Entrance Exam in 2011.

\section{B. Instruments for Data Collection}

The instrument used in this study is mainly quantitative study, including a questionnaire and two vocabulary tests. The qualitative method is also used in analyzing the data from the interview.

\section{Vocabulary Test}

The subjects in this study were arranged to attend two tests: a pre-test and a post-test.

The vocabulary pre-test used in this study was designed according to Laufer's (1998) distinction about English words (passive words, controlled active words and free active words) and the core vocabulary according to College English Syllabus. The twenty-five words in the pre-test are selected randomly from all the core vocabulary from the first two lessons in Book Two, New Horizon College English. Because free active words are difficult to control, the pre-test paper only includes: passive words and controlled-productive words.

The purpose of this pre-test was to determine whether the subjects in the two groups were qualified for this study.

The second vocabulary test, for examining the controlled-productive and free-productive vocabulary, was designed according to Laufer and Nation's (1999) test to controlled productive vocabulary. Forty positive words were chosen randomly from the core vocabulary taken from Unit 3 to Unit 5 according to the College English Teaching syllabus and the core vocabulary in Band-4 and Band-6 examination.

\section{Questionnaire}

The questionnaire in this study was carried out in the following week after finishing all the teaching experiment. The subjects were the thirty-seven students in the experimental class. The purpose is to find out the students' attitudes towards the new vocabulary learning model under the environment of internet and multimedia, so as to improve it and make it more feasible in the future teaching practice. The questionnaire in this study was designed according to Liu Runqing (1999). All the statements are presented in Appendix 3, and the key to understand the average mark is presented in the last part of Appendix 3. Each of the statement has five choices ranging from 'strongly agree' to 'strongly disagree' (5/4/3/2/1) in the form of Likert 5 point scale. Students were required to mark a number in each item. In order to avoid misunderstanding, the questionnaire was handed out in Chinese version.

\section{Procedures for Data Collection}

In this study, there were two variables: vocabulary learning method and vocabulary test scores. Therefore, data collection in this study mainly prepared from these two aspects. The steps of collecting data in this study mainly undertaken like this:

\section{Step 1: A pre-test}

After the pre-experimental teaching (the core vocabulary in the first two lessons were taught to all the subjects by adopting the traditional vocabulary teaching method), asking them to complete the pre-test paper, so as to find out whether the two groups were qualified for this study.

Step 2: A nearly fifty-day teaching experiment.

Asking the students in Class 1 (the controlled group: group 1) and Class 2 (the experimental group: group 2) to deal with the positive words from lesson 3 to lesson 6 in different ways. Choosing twenty active words according to the teaching syllabus and Band-4 and Band-6 examination in each lesson and asking the two groups to prepare for the words before each class. In class, group 1 adopted the traditional vocabulary learning way (i.e., teacher as the source of 
word knowledge, explaining, repeating and asking students to take notes about each required positive word). Group 2 adopted a new vocabulary learning method which was guided by the social constructivist model with the aid of internet and multimedia. That is, according to the values and beliefs of social constructivist model, instead of imparting word knowledge to students from beginning to the end in the class time, with the help of computer and multimedia, asking students to watch film clips about the topics of each lesson and encouraging them to note down the words they are unfamiliar with, then organizing them to create real-life situations to construct the word knowledge by themselves. Specifically speaking, first dividing students into some groups: in each group there is a group leader who is responsible for the organization of the group discussion and a secretary who is responsible for taking notes. During the group discussion, the students are allowed to use internet to consult reference materials, or present their associations and findings of the target word; they are even allowed to produce ill-structured sentence and some Chinese in discussion. The atmosphere is relaxed and lively, and the students are very free and active in activating the syntagmatic and paradigmatic relations of the target words. Of course, the teacher and learners also interact with each other. The teacher walks around the classroom and tries to encourage learners to output the newly-learned words as they input them. In short, learners construct their vocabulary knowledge in real-world contexts, and the four elements: teacher, task, learner and the context are in this way a dynamic equilibrium.

\section{Results AND ANALYSIS}

\section{A. Results from the Pre-test}

The following two tables show the results from the statistics of the controlled group (group 1) and experimental group (group 2) in the pre-test.

TABLE 1

DESCRIPTIVE STATISTICS OF PRE-TEST

\begin{tabular}{|l|l|l|l|l|}
\hline \multirow{2}{*}{ score } & group & Number & Mean & SD \\
\cline { 2 - 5 } & 1 & 37 & 17.68 & 3.793 \\
\cline { 2 - 5 } & 2 & 37 & 16.97 & 4.463 \\
\hline
\end{tabular}

From table 1, we can find that the mean of group 1 (17.68) is a little higher than that of group 2 (16.97). And the standard deviation in table 1 indicates that the deviation of group 2 is a bit more deviant away from the central point in the distribution than that of group 1 . However, we can not find whether there exists significant difference between the two groups just from Table 1.

TABLE 2

INDEPENDENT SAMPLES TEST OF PRE-TEST

\begin{tabular}{|c|c|c|c|c|c|c|c|}
\hline & & \multicolumn{2}{|c|}{$\begin{array}{l}\text { Levene's Test } \\
\text { for Equality of } \\
\text { Variances }\end{array}$} & \multicolumn{4}{|c|}{ t-test for Equality of Means } \\
\hline & & $\mathrm{F}$ & Sig. & $\mathrm{t}$ & Sig.(2-tailed) & \multicolumn{2}{|c|}{$95 \%$ Confidence Interval of the Difference } \\
\hline \multirow[t]{2}{*}{ score } & $\begin{array}{l}\text { Equal variances } \\
\text { assumed }\end{array}$ & 1.515 & .222 & .748 & .457 & -1.183 & 2.064 \\
\hline & $\begin{array}{l}\text { Equal variances } \\
\text { not assumed }\end{array}$ & & & .748 & .457 & -1.183 & 2.604 \\
\hline
\end{tabular}

Table two indicates that there is no significant difference between the two groups in the pre-test, for the 2-tailed significance is $0.457(\mathrm{P}>.05)$, it is obvious that the value doesn't fall between 0 and 0.05 . Therefore, there is no obvious significant difference on vocabulary level between the two groups before the teaching experiment, and the two groups are qualified for this experimental study.

\section{B. Results from the Post-test}

\section{About Free-productive Vocabulary.}

TABLE 3

A DESCRIPTIVE ANALYSIS OF THE FREE-PRODUCTIVE VOCABULARY IN THE POST-TEST
\begin{tabular}{|l|l|l|l|l|}
\hline & group & Number & Mean & SD \\
\hline \multirow{2}{*}{ score } & 1 & 37 & 71.08 & 10.734 \\
\cline { 2 - 5 } & 2 & 37 & 78.14 & 9.670 \\
\hline
\end{tabular}

This table shows that after the teaching experiment, the students in the experimental group got higher average score (mean=78.14) than those of the controlled group (mean=71.08). The standard deviations of the two groups (group 1: 10.734; group 2: 9.670) prove that the students' average score in the controlled group spread a bit wider from the central point in the distribution than those of the experimental group. 
TABLE 4

INDEPENDENT SAMPLES TEST FOR FREE-PRODUCTIVE VOCABULARY

\begin{tabular}{|c|c|c|c|c|c|c|c|}
\hline & & \multicolumn{2}{|c|}{$\begin{array}{l}\text { Levene's Test for Equality of } \\
\text { Variances }\end{array}$} & \multicolumn{4}{|c|}{ t-test for Equality of Means } \\
\hline & & \multirow[b]{2}{*}{$\mathrm{F}$} & \multirow[b]{2}{*}{ Sig. } & \multirow[b]{2}{*}{$\mathrm{t}$} & \multirow{2}{*}{$\begin{array}{l}\text { Sig. } \\
\text { 2-tailed }\end{array}$} & \multicolumn{2}{|c|}{$95 \%$ Confidence Interval of the Difference } \\
\hline & & & & & & lower & upper \\
\hline \multirow[t]{2}{*}{ score } & $\begin{array}{l}\text { Equal variances } \\
\text { assumed }\end{array}$ & .993 & .322 & -2.951 & .004 & -11.817 & -2.287 \\
\hline & $\begin{array}{l}\text { Equal variances not } \\
\text { assumed }\end{array}$ & & & -2.946 & .004 & -11.825 & -2.278 \\
\hline
\end{tabular}

Through the Independent-Sample T-test, the above table shows that the 2-tailed significance is 0.004 ( $p<0.05)$, it is obvious that there is a significant difference in producing the free-productive words between the two groups. $95 \%$ confidence interval of the difference indicates that the significant difference in producing the free-productive vocabulary is at the 0.05 level.

\section{About Controlled-productive Words}

TABLE 5

A DESCRIPTIVE ANALYSIS OF THE CONTROLLED-PRODUCTIVE VOCABULARY IN THE POST-TEST

\begin{tabular}{|l|l|l|l|l|}
\hline & group & Number & Mean & SD \\
\hline \multirow{2}{*}{ score } & 1 & 37 & 14.13 & 4.205 \\
\cline { 2 - 5 } & 2 & 37 & 14.68 & 3.575 \\
\hline
\end{tabular}

The mean in the experimental group (group 2) is a little higher than that of the controlled group (group 1), and the standard deviation shows that the scores in group 1 spread more widely than those for group 2.

TABLE 6

INDEPENDENT SAMPLES TEST OF CONTROLLED-PRODUCTIVE VOCABULARY IN THE POST-TEST

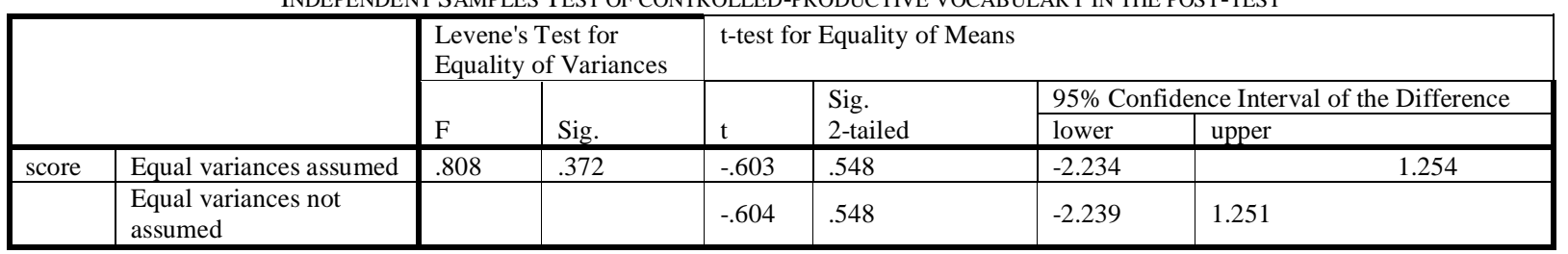

Table 6 indicates that there is no significant difference on the scores of the controlled-productive words between the two groups after the teaching experiment, for the probability of 2-tailed t-test is $0.548(\mathrm{p}>.05)$.

On the basis of the analyses of these four tables, we can easily find that there is positive correlation between students' vocabulary test scores and their application of the social constructivist model under internet and multimedia environment, especially in their production of the free-productive words. While to the controlled-productive words, the differences between the two groups were not so obvious.

\section{Results from the Questionnaire}

TABLE 7

A DESCRIPTIVE ANALYSIS ABOUT STUDENTS’ ATTITUDES TOWARDS THE NEW VOCABULARY LEARNING MODEL

\begin{tabular}{|l|l|l|l|}
\hline $\begin{array}{l}\text { Overall } \\
\text { average }\end{array}$ & Attitude & Number & $\begin{array}{l}\text { Frequency } \\
(\%)\end{array}$ \\
\hline $4.5-5.0$ & strongly agree & 2 & 5.41 \\
\hline $3.5-4.4$ & agree & 19 & 51.35 \\
\hline $2.5-3.4$ & Comparatively agree & 12 & 32.43 \\
\hline $1.5-2.4$ & disagree & 4 & 10.81 \\
\hline $1.0-1.4$ & strongly disagree & 0 & 0 \\
\hline
\end{tabular}

The above table indicates that there are more than eighty percent of the total students agree or comparatively agree with the new vocabulary learning model guided by social constructivist model under internet and multimedia environment. However, two students show strongly agreement to this vocabulary learning model, this also indicates that this model still needs great improvement.

\section{CONCLUSION AND FurThER RESEARCH}

On the basis of the above mentioned comparative analysis between the experimental group and the controlled group, we can find that the social constructivist model supported by internet and multimedia does have certain influence on students' vocabulary learning, especially on their free-productive vocabulary acquisition. Though there is no clear significant difference between the two groups about their controlled-productive vocabulary, the mean between them can, more or less, demonstrate the effect of social constructivist model in helping learners improve their vocabulary 
competence.

In order to improve and make the new vocabulary learning model more feasible in the future vocabulary teaching and learning, a questionnaire about learners' attitudes towards the new vocabulary learning model under internet and multimedia environment was followed after the teaching experiment. The results were comparatively satisfactory and very beneficial to the improvement of our new vocabulary learning model. Social constructivist model emphasizes the dynamic nature of the interplay among teachers, learners, tasks and contexts in students' vocabulary learning. It is important to note that only with the help of modern technology, that is the computer and multimedia, can the four factors (learners, tasks, teachers and contexts) interact in an effective dynamic state and learners construct their vocabulary knowledge actively and effectively.

The correlation between the vocabulary test scores and the application of social constructivist model under internet and multimedia environment shows the function of this model in vocabulary acquisition, especially in the free-productive vocabulary acquisition. The results of this study, in a sense, help the learners shorten the gap between their receptive and productive vocabulary.

According to the results of this study, we attempt to put forward a new vocabulary acquisition model which combines the acquisition with production: combination of input and output. That is, under the environment of internet and multimedia, asking students to output the newly-learned words in social interactive situations which created by themselves as they input the new words. Of course, this is just an attempt. It requires teachers to have a good command of the background information about educational psychology, for the way that teachers behave in the classroom reflects their values and beliefs towards vocabulary acquisition. And vocabulary acquisition itself is very complicated to deal with.

In addition, though comparatively satisfactory results were obtained from this study, the subjects in this study are freshmen of non-English majors. This may affect the generalization of the result. It is sure that this study is not an end but a start point for further research in a wider field. The future studies about the application and effects of this model on vocabulary acquisition to sophomores, juniors, seniors, and English majors are called for and welcomed.

\section{APPENDIX 1}

\section{Pre-test}

1. Filling in the blanks with the help of the given letters.

1) A student with ave___ intelligence is a student neither very bright nor very dull.

2) You should con__ your attention on the study.

3) He dou_ his English vocabulary in one year.

4) In s_ of the bad weather, she is still working.

5) The dictionary is very hel to me.

6) She holds a very good att___ towards her work.

7) Though she is nearly 64, Julia doesn't want to re

8) At the age of nearly sixty-five, Chichester began the greatest voy of his life.

9) The boy con___ his fear of the dark and walked alone in the woods at night.

10) The earthquake did serious dam___ to the small town.

11) Would you please $f \_$in your name, address and telephone number here?

12) Food that looks good doesn't nec__ taste good.

13) Oliver's father tried to dis__ him from marrying Jenny.

14) Have you dec___ on a date for your departure?

15) I always con___ you with your sister because you look so alike.

2. There are ten incomplete sentences in this part. For each sentence there are four choices marked A, B, C and D. Choose the one that best completes the sentence.

1) I've read the book and I've seen the film
A. as usual
B. as well
C. either
D. too

2) $\mathrm{He} \_$his notes several times before the final exam.

A. went in for B. went into C. went out D. went over

3) Have you ___ some money for possible emergency?
A. set down
B. set out
C. set out
D. set aside

4) The earthquake ___ serious damages.
A. leads to
B. results from
C. lies in
D. leads on

5) This is the __ pen he used when he was writing the book.
A. very
B. exact
C. well
D. that

6) At sixty-five, Francis Chichester decided to sail
A. sole
B. lonely
C. singularly
D. single-handed round the earth.

7) During the accident, the ship ___ and people lost their lives in the sea.
A. turned over
B. turned off C. turned down

8) David argued with his father for hours, but he had to in the end.

D. turned up 

A. give out
B. give in
C. give up
D. give away

9) $\mathrm{He}$ to sail round the world all by the age 65 .
A. set up
B. set out
C. set on
D. set off

10) Whenever I look at the picture, it.
A. can't help admire
B. can't help but admire
C. can't help admiring
D. would admire

\section{APPENDIX 2}

\section{Post-test Paper}

\section{Part One: (About Controlled-productive words)}

Filling in the blanks with the help of the given letters

1. Tom bought her a bun of flowers as a birthday gift.

2. Please tell the secretary to arr a meeting for the announcement of new personnel.

3. She is a very eff secretary; she never forgets anything or makes a mistake.

4. The old man st to pick up the wallet.

5. The pri cause of his failure is his laziness.

6. With telephone, we can com with people anywhere all over world.

7. Her anx to succeed pushed her to work harder.

8. Wish you a $\mathrm{m}$ Christmas and a happy new year.

9. He is too young to know right from w

10. I am so ama__ by the news that he won the game.

11. History is the most bor___ lesson for us.

12. The government is making great effort to dec the unemployment.

13. Because his family was very poor, he had to drop out of the school only after the ele

14. Laying a good fou of the building is the most important step.

15. Aspirin usually can rel a headache.

16. He has many good qua____---diligence, modesty and simplicity.

17. I sam__ the biscuit and found it very good.

18. He has got some money for the pur of his favorite books.

19. His parents can't aff_the tuition for his study in college.

20. Henry is very strict with his son. He only lets him watch TV occ

\section{Part Two: (About Free-productive Words)}

This is a kind of vocabulary test which is called VKS (Vocabulary Knowledge Scale). Please choose the right number according to your knowledge to the words and finish the exercises according to the directions.

Self-report categories:

1) I don't remember having seen this word before.

2) I have seen this word before, but I don't know what it means.

3) I have seen this word before, and I think it means

4) I know this word. It means (synonym or translation) (synonym or translation)

5) I can use this word in a sentence: . (Write a sentence.) (If you do this section, please also do Section4.)

1. endure

2. reluctantly

3. operate

4. rare

5. divorce

6. involve

7. worthwhile

8. prohibit

9. in part

10. indignant

11. grown-up

12. weep

13. promote

14. flow

15. productive

16. inspect

17. select

18. to one's taste

19. long for

20. delicious

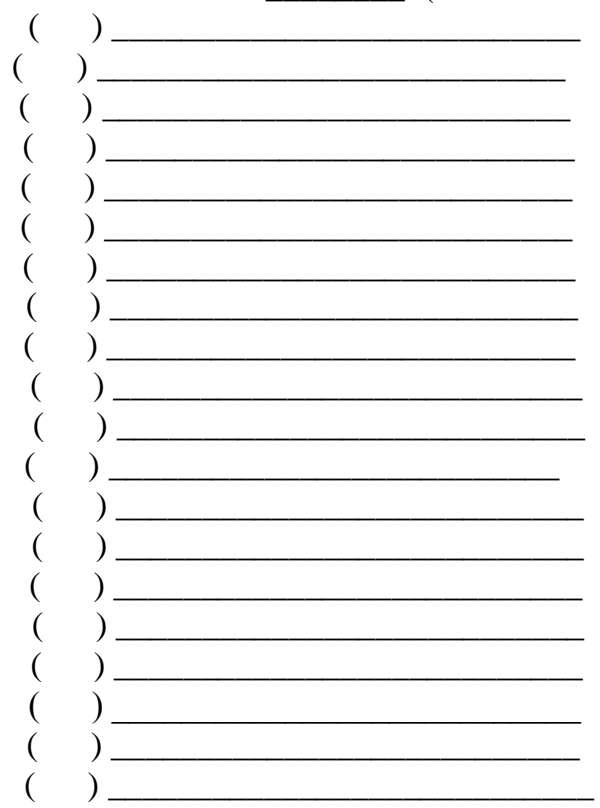




\section{APPENDIX 3}

\section{Questionnaire}

(This is a questionnaire about students' attitudes and feelings towards the multimedia-based social constructivist model during their nearly fifty days vocabulary study. In order to avoid misunderstanding, the handouts were delivered in Chinese version.)

Please read the following statements carefully, and answer in terms of how well the statement describes you. Do not answer how you think you should be, or what other students do. There is no right or wrong answers to these statements. Write your answers in the bracket after each statement.

1. Strongly disagree

2. Disagree

3. Comparatively agree

4. Agree

5. Strongly agree

1) I think the new vocabulary learning model fits me well.( )

2) I think the new vocabulary learning model that 'output as we input' is helpful to our oral expression improvement. ( )

3) I think learning vocabulary in an interactive classroom situation can relieve my anxiety. ( )

4) I prefer the new vocabulary learning method to the traditional teacher-centered one. ( )

5) I think it is light and relaxed to learn English words in interactive situations. ( )

6) I think the words constructed by myself are not easily Forgotten. ( )

7) I think the vocabulary that acquired through interaction can be easily transferred to our long-term memory. ( )

8) I think the words acquired in the interactive classroom environments can easily become our active vocabulary. ( )

9) I think the new vocabulary learning model can help us to associate what we've learned in the past, so as to improve our memory retention. ( )

10) I think the new vocabulary learning model can help us to associate the synonyms, antonyms and collocations of the new words. ( )

11) The new vocabulary learning model builds up my confidence in learning foreign vocabulary. ( )

12) The new vocabulary learning model enhances my enthusiasm in vocabulary learning. ( )

13) The new vocabulary learning model makes me more aware of the purpose of vocabulary learning. ( )

14) The new vocabulary learning model helps me adopt a better attitude towards my role in class. ( )

15) The new vocabulary learning model helps me overcome the fears of being questioned by teachers in class. ( )

16) The interactive classroom atmosphere can favorably shorten the gap between us and teachers. ( )

17) The interactive classroom atmosphere can help us understand better and study more effectively. ( )

Key to Understanding your average mark

Strongly agree------------------------5

Agree----------------------------------4

Comparatively agree-------------------3

Disagree--------------------------------2

Strongly disagree------------------------1

Please sum up your responses $(1,2,3,4,5)$ to each statement and then get the overall average. Write down the average points on the top of this questionnaire.

\section{REFERENCES}

[1] Doughty, C. and T. Pica. (1986). 'Information gap' tasks: do they facilitate second language acquisition? TESOL Quarterly 20:305-325.

[2] Du Xiaohong. (2009). A Study on English Grammar Teaching Model to College Students Majoring in English Education, Shandong Foreign Language Teaching (5): 42-45.

[3] Du Xiaohong. (2011). On Dynamic Equilibrium between Implicit Grammatical Knowledge and Explicit Grammatical Competence. Contemporary Foreign Language Studies (7): 26-29.

[4] Laufer, B. (1998). The Development of Passive and Active Vocabulary in a Second Language: Same or different? Applied Linguistics, 19: 255-271.

[5] Laufer, B. \& Nation, P. (1999). A vocabulary-size test of controlled productive ability'. Language Testing, 16, 1: 33-51.

[6] Liu Runqing. (1999). Research Methodology in Foreign Language Teaching. Beijing: Foreign Language Teaching and Research Press.

[7] Marion William \& Robert L. Burden. (1997). Psychology for Language Teachers, Foreign Language Teaching and Research Press: 5, 7-29, 30-44.

[8] Zheng Shutang. (2008). New Horizon College English (Book 1), Beijing: Foreign Language Teaching and Research Press.

Xiaohong Du was born in Xuchang, China, in 1973. She received her MA in Applied Linguistics from Hubei University in 2004, 
Wuhan, China, and a BA in English Education from Henan Normal University in 1997, Xinxiang, China. Her main research interests are linguistics and foreign language teaching.

She has been teaching English for 15 years and now she is an associate professor in Zhengzhou University, Zhengzhou, China. From Sep 1, 2012 to Sep1, 2013, she is an academic visitor in the Centre of Intercultural Research in Communication and Learning (CIRCL) at De Montfort University, UK.

Associate professor Du is an IELTS Invigilator and a Cambridge ESOL Oral Examiner (BEC Preliminary / Vantage /Higher Level) in Zhengzhou, China. She is also an honorary associate professor of De Montfort University, UK from Sep 1, 2012 to Sep1, 2013. 